\title{
La emisión acústica aplicada al estudio del deterioro de la piedra en ensayos de cristalización con sulfato de sodio
}

\section{The application of the acoustic emission technique to stone decay by sodium sulphate in laboratory tests}

Fecha de recepción: 25-XI-96

Fecha de aceptación: $20-X I I-96$
C. M. GROSSI, R. M. ESBERT y L. M. SUÁREZ DEL RÍo Depto. de Geología. Universidad de Oviedo ESPAÑA

\section{RESUMEN}

Para determinar los mecanismos de deterioro de las rocas debidos a la acción del sulfato de sodio, se ha registrado la emisión acústica durante ensayos de cristalización de sales en el laboratorio. Para ello, se han seleccionado tres piedras porosas carbonatadas utilizadas como materiales de construcción en monumentos españoles (Catedrales de Oviedo, Murcia y Seo Vella de Lérida).

La emisión acústica detectada durante las diferentes etapas de los ciclos (inmersión, secado y enfriamiento) se ha interpretado como debida al comportamiento de la sal en el interior de la piedra. Mediante esta técnica se ha confirmado que este comportamiento depende de las caracteristicas de la sal (solubilidad, diferentes estados de hidratación y el polimorfismo del sulfato de sodio anhidro) $y$ de la porosidad y configuración del sistema poroso de las rocas.

\section{SUMMARY}

Acoustic emission was monitored during salt crystallisation cycles in order to study the mechanisms of rock deterioration by sodium sulphate in laboratory tests. Some porous carbonate stones used in Spanish monuments (Cathedral of Oviedo, Murcia and Seo Vella of Lérida) were selected for this study.

The acoustic emission detected during the different stages of the cycles (immersion, drying and cooling) was interpreted to be the result of the salt behaviour inside the stone. The use of this technique has confirmed that this behaviour depends on salt characteristics (solubility, hydration state and polymorphism of anhydrous sodium sulphate) and stone porosity and pore network.

\section{INTRODUCCIÓN}

Las sales solubles son uno de los principales agentes de deterioro de las rocas de los monumentos. Por ello forman un apartado individual de estudio dentro del ámbito de su conservación-restauración.

Una de las tendencias actuales en este campo es el uso de ciertas técnicas no destructivas para el estudio de los mecanismos y causas de alteración de las piedras

\section{INTRODUCTION}

Soluble salts are one of the main causes of building stone decay. Therefore they constitute an individual subject of study in the Conservation and Restoration of monuments made of stone.

One of current trends in this field is the use of some non-destructive techniques (NIT) to study the mechanisms and causes of stone decay on-site. One 
de los monumentos. Una de estas técnicas es la conocida como Emisión Acústica/Actividad Microsísmica (EA/AM).

La emisión acústica o actividad microsísmica consiste en la liberación espontánea de energía en forma de ondas elásticas por un material cuando está sometido a tensiones. En las rocas puede estar relacionada con procesos de deformación y rotura como dislocaciones de la red cristalina, maclaciones, movimientos intergranulares, generación y propagación de fisuras, etc.

Los esfuerzos generados por las sales en el interior de una roca porosa pueden dar lugar a una liberación de energía en forma de ondas elásticas (emisión acústica) que pueden ser registradas y analizadas (1). La interpretación de los resultados obtenidos por esta técnica no es sencilla, especialmente cuando se aplica in situ, debido a la variedad de procesos que pueden ser generadores de EA.

La diferencia de la técnica de emisión acústica con la técnica de ultrasonidos es que en ésta se utilizan dos transductores, uno, emisor, que genera una señal mecánica en el material que se está estudiando, y otro, receptor, que recoge la señal modificada. En contraste, en la EA/AM solamente se utiliza un transductor receptor que recoge las señales "autogeneradas" en el material (2) (Fig. 1). of these techniques is Acoustic Emission/Microseismic Activity (AE/MS).

When rocks or structures are subjected to stress, elastic waves are spontaneously generated, these being called "acoustic emission" or "microseismic activity". In rock materials, the acoustic emission can be related to deformation and failure processes, like crystal dislocation, twinning, intergranular movements, generation and propagation of fissures, etc.

Stresses generated by salts inside the stone can originate a release of energy in the form of elastic waves (acoustic emission) which can be recorded and analysed (1).The interpretation of the results obtained by this technique is complex, specially when applied on-site, due to the different processes that can generate acoustic emission.

The difference with ultrasonic technique is that ultrasonic technique utilises two transducers; one, a transmitter, generates a mechanical signal within the material under study; the other, a receiver, monitors the modification of the transmitted signal. In contrast, the AE/MS technique utilises only a receiving transducer that monitors self-generated signals occurring within the material (2)(Fig. 1).

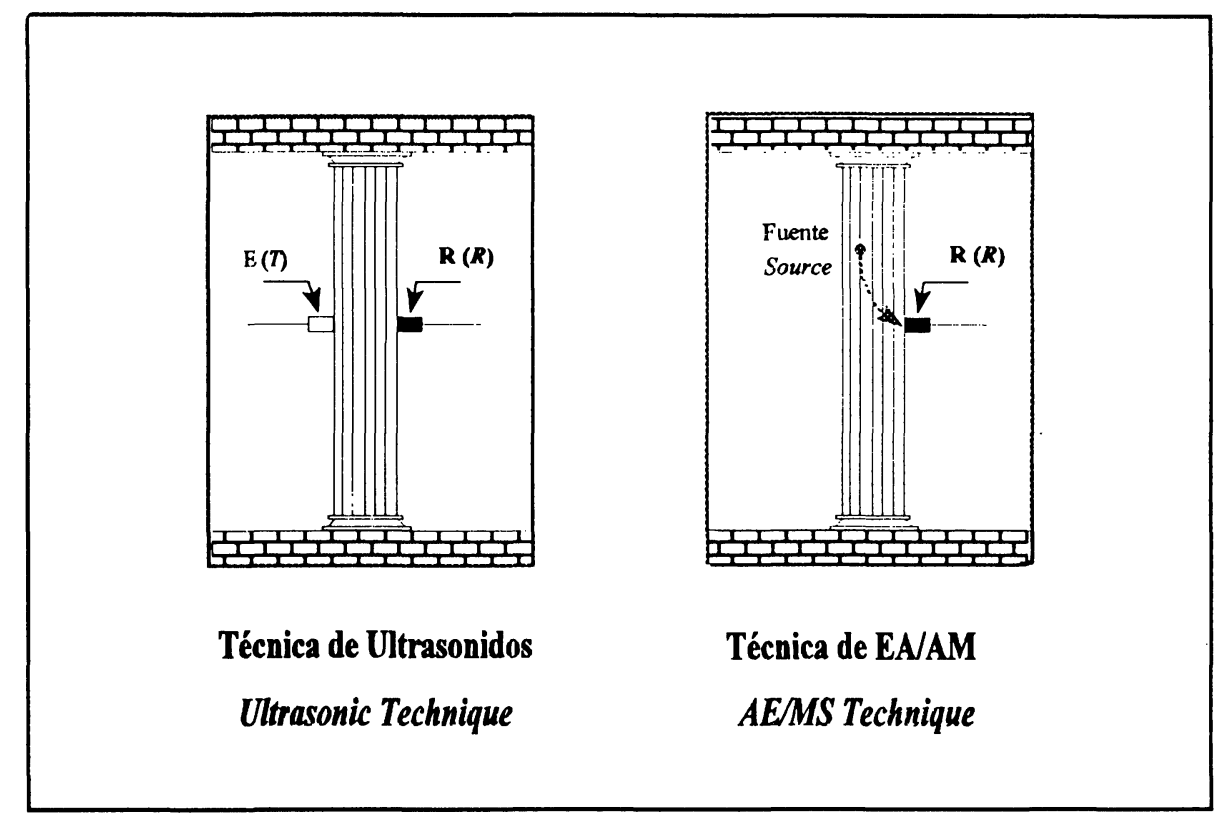

Fig. 1.- Representación esquemática de la generación y recogida de señales mediante técnicas de ultrasonidos (izquierda) y emisión acústica/actividad microsísmica (derecha). E: Transductor emisor; R: Transductor receptor.

Fig. 1.- Scheme of the generation and monitoring of signals by ultrasonic (left) and acoustic emission/microseismic activity (right) techniques: T: Transmitter transducer; R: Receiving transducer. 


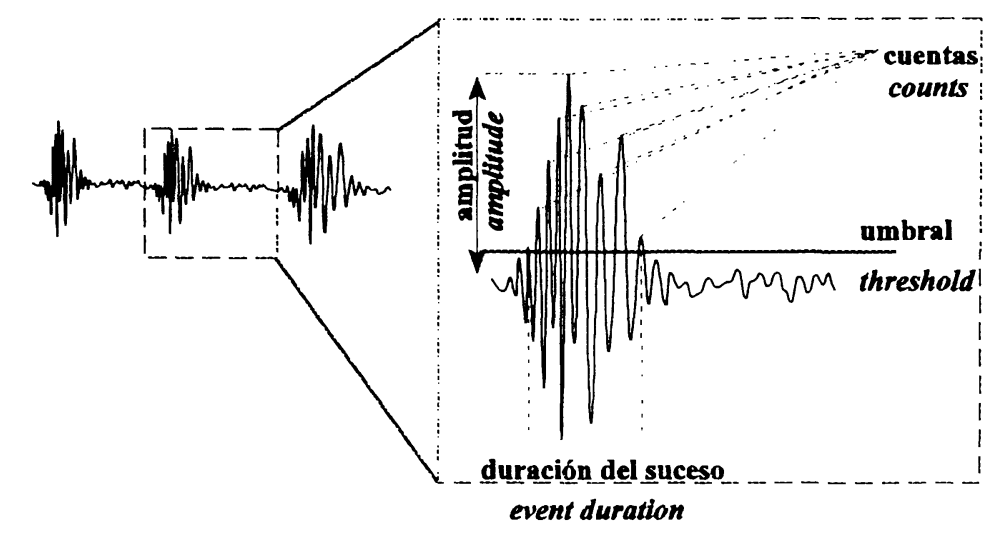

Fig. 2.- Sección típica de un registro de EA/AM y expansión de un suceso en el que se señalan algunos parámetros a considerar en su estudio.

Fig. 2.- Typical section of AE/MS data and expanded AE/MS event in which some parameters to be studied are shown.

Como medida de la emisión acústica suele utilizarse la velocidad de emisión acústica, expresada en sucesos o cuentas por unidad de tiempo. Un suceso es cada uno de los cambios físicos producidos en el material capaz de generar emisión acústica. Cada suceso está formado por un número variable de cuentas (cada uno de los picos del tren de ondas del suceso por encima del umbral de ruido de fondo) (Fig. 2).

El equipo básico para el registro de emisión acústica es bastante sencillo: un transductor, un sistema de amplificación y un equipo de registro. También se suele incluir un sistema de filtrado para eliminar señales no deseadas, tanto de alta como de baja frecuencia.

En este trabajo se ha registrado la emisión acústica durante los ciclos de cristalización de sales para estudiar los mecanismos de deterioro de la piedra por el sulfato de sodio en ensayos de laboratorio.

\section{MATERIALES}

De entre las piedras utilizadas en el Patrimonio Monumental Español, se seleccionaron tres rocas carbonatadas con diferente porosidad y configuración del sistema poroso: las dolomías de Vinaixa y Laspra (empleadas en la Seo Vella de Lérida y en la Catedral
The "AE rate", that is the number of "events" or "counts" per unit of time, is the more usual way to measure acoustic emission, an "event" being each physical change in the material able to produce acoustic emission. Each event is formed by a variable number of "counts" (each peak of the wave train above the background noise threshold of the monitored event) (Fig. 2).

The basic equipment for AE/MS monitoring is quite simple: a transducer, an amplification system and a recording equipment. A band-pass filter is also normally included in such systems in order to eliminate undesirable extraneous low and high frequency signals.

In this paper, $A E$ was monitored during salt crystallisation cycles in order to study the mechanisms of rock deterioration by sodium sulphate in laboratory tests.

\section{MATERIALS}

Three carbonate stones from the Spanish Monumental Heritage with different porosity and pore network have been selected: Vinaixa and Laspra dolomites (used in the Seo Vella of Lérida and in the Cathedral of Oviedo, respectively) and 
de Oviedo, respectivamente) y la caliza de Murcia (usada en la Catedral de Murcia) (Fig. 3a, b y c y Tabla I).

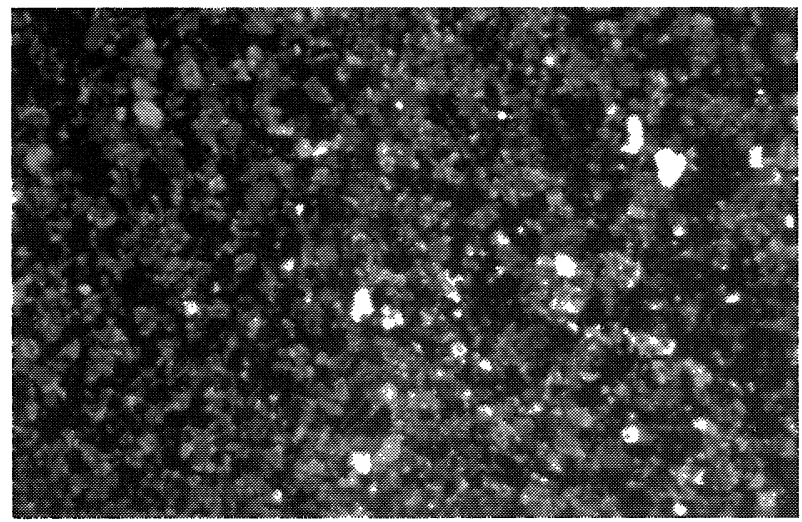

a
Murcia limestone (used in the Cathedral of Murcia) (Fig. $3 a, b$ and $c$ and Table I).

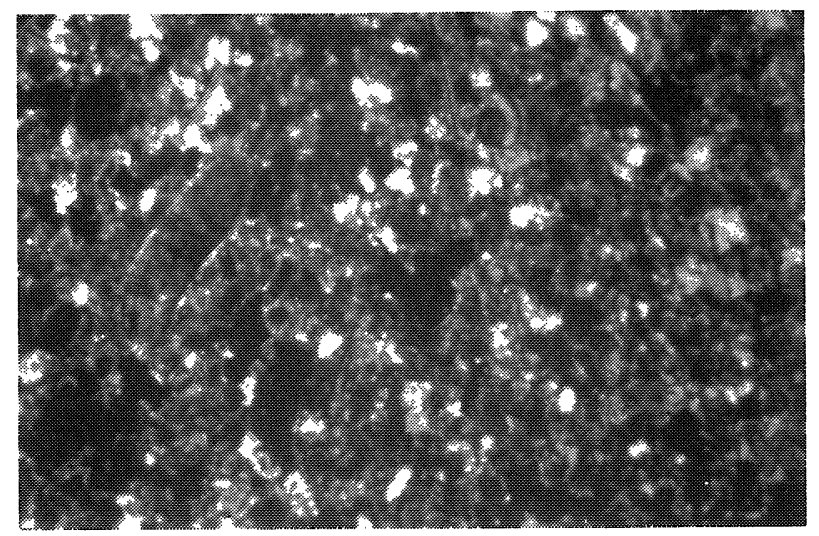

b

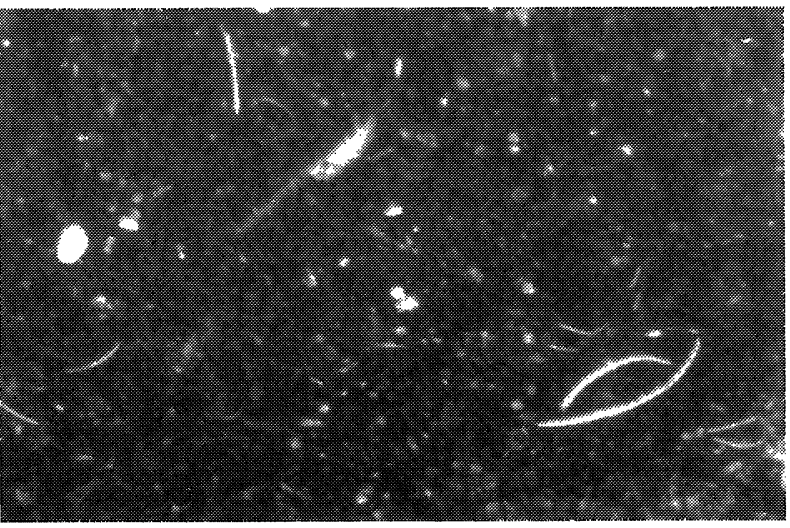

c

Fig. 3.- Aspecto de la textura de las rocas a) Vinaixa, b) Murcia y c) Laspra al microscopio óptico de polarización (Lado mayor = 2,1 mm; $2,1 \mathrm{~mm}$ y 3,5 mm, respectivamente).

Fig. 3.- Rock textures under polarizing microscope a) Vinaixa, b) Murcia and c) Laspra (longest side $=2.1 \mathrm{~mm} ; 2.1 \mathrm{~mm}$ and $3.5 \mathrm{~mm}$, respectively).

\section{TABLA I (TABLE I)}

Características del sistema poroso de las rocas estudiadas obtenidas mediante porosimetría de mercurio

(Pore network characteristics of the studied stones by mercury porosimetry)

\begin{tabular}{||c|c|c|c|c|c||}
\hline $\begin{array}{c}\text { Piedra } \\
\text { Stone }\end{array}$ & $\begin{array}{c}\text { Porosidad } \\
\text { abierta (\%) } \\
\text { open porosity } \\
(\%)\end{array}$ & $\begin{array}{c}\text { \% poros con } \\
\text { radio }>7,5 \mu \mathrm{m} \\
\% \text { pore } \\
\text { radius }>7.5 \mu \mathrm{m}\end{array}$ & $\begin{array}{c}\text { \% poros con } \\
\text { radio entre } \\
7,5 \mu \mathrm{m}-1 \mu \mathrm{m} \\
\% \text { pore radius } \\
7.5 \mu \mathrm{m}-1 \mu \mathrm{m}\end{array}$ & $\begin{array}{c}\text { \% poros con } \\
\text { radio < } 1 \mu \mathrm{m} \\
\% \text { pore } \\
\text { radius }>1 \mu \mathrm{m}\end{array}$ & $\begin{array}{c}\text { Radio de poro } \\
\text { (media- } \mu \mathrm{m}) \\
\text { Average pore } \\
\text { radius }(\mu \mathrm{m})\end{array}$ \\
\hline Vinaixa & 15 & 3,2 & 76,5 & 20,3 & 5 \\
\hline Murcia & 30 & 43,3 & 24,2 & 32,5 & 8 \\
\hline Laspra & 31 & 1,6 & 4 & 94,4 & 0,4 \\
\hline
\end{tabular}




\section{PROCEDIMIENTO EXPERIMENTAL}

El ensayo de cristalización de sales realizado se ha basado en las recomendaciones de la RILEM (1980) (3), aunque con algunas modificaciones. Cada ciclo ha constado de tres etapas:

1) Inmersión: 4 horas en solución acuosa al $14 \%$ de sulfato sódico decahidratado (a una temperatura aproximada de $20^{\circ} \mathrm{C}$ ).

2) Secado: 14 horas en un horno con ventilación forzada, precalentado a $60^{\circ} \mathrm{C}$

3) Enfriamiento: 6 horas en condiciones ambientales $\left(\mathrm{T}=18-20^{\circ} \mathrm{C} ; \mathrm{HR}=70-75 \%\right)$.

La emisión acústica se registró a lo largo de los ciclos, en cuentas por segundo, con un equipo Spartan 3000 (Physical Acoustic Corporation, NJ, USA), usándose transductores piezoeléctricos (R15, Physical Acoustic Corporation) con una frecuencia de resonancia de 150 $\mathrm{kHz}$. Se utilizó un filtro de paso de banda de $100-300 \mathrm{kHz}$. El almacenamiento y procesado de señales se realizó con un ordenador personal acoplado, también de la misma firma comercial.

Para evitar que el transductor se humedeciese o calentase durante el ensayo, se pegó a la superficie superior de las probetas durante la inmersión y enfriamiento, y fuera de la estufa, durante el secado, utilizando en este caso una "varilla guía" de vidrio PYREX, conductora de las ondas sónicas. En la Fig. 4 se representa el monitorizado de emisión acústica durante las tres etapas de cada ciclo.

\section{EXPERIMENTAL PROCEDURE}

The recommendations of the RILEM (1980) (3) for the salt crystallisation ageing test have been followed with some modifications. Each cycle was performed in three stages:

1) Immersion: 4 hours in a 14\% aqueous solution of sodium sulphate decahydrate (at approximately $20^{\circ} \mathrm{C}$ ).

2) Drying: 14 hours in an oven with forced ventilation preheated at $60^{\circ} \mathrm{C}$.

3) Cooling: 6 hours at room conditions $\left(T^{\prime}=18-20^{\circ} \mathrm{C}\right.$; $R H=70-75 \%)$.

Acoustic emission rate (in counts/second) was continuously monitored during each cycle with a Spartan 3000 equipment using a piezoelectric transducer with a resonant frequency of $150 \mathrm{kHz}$. A 100-300 kHz band-pass filter was employed. Signal recording and processing were carried out using $a$ coupled personal computer.

In order to avoid transducer wetting and heating during the test, it was bonded to the specimen's upper surface during immersion and cooling and placed outside the oven when drying. In this case, the transducer was connected to the stone surface by means of a PYREX glass wave guide Fig. 4 shows the acoustic emission monitoring during the three stages of each cycle.

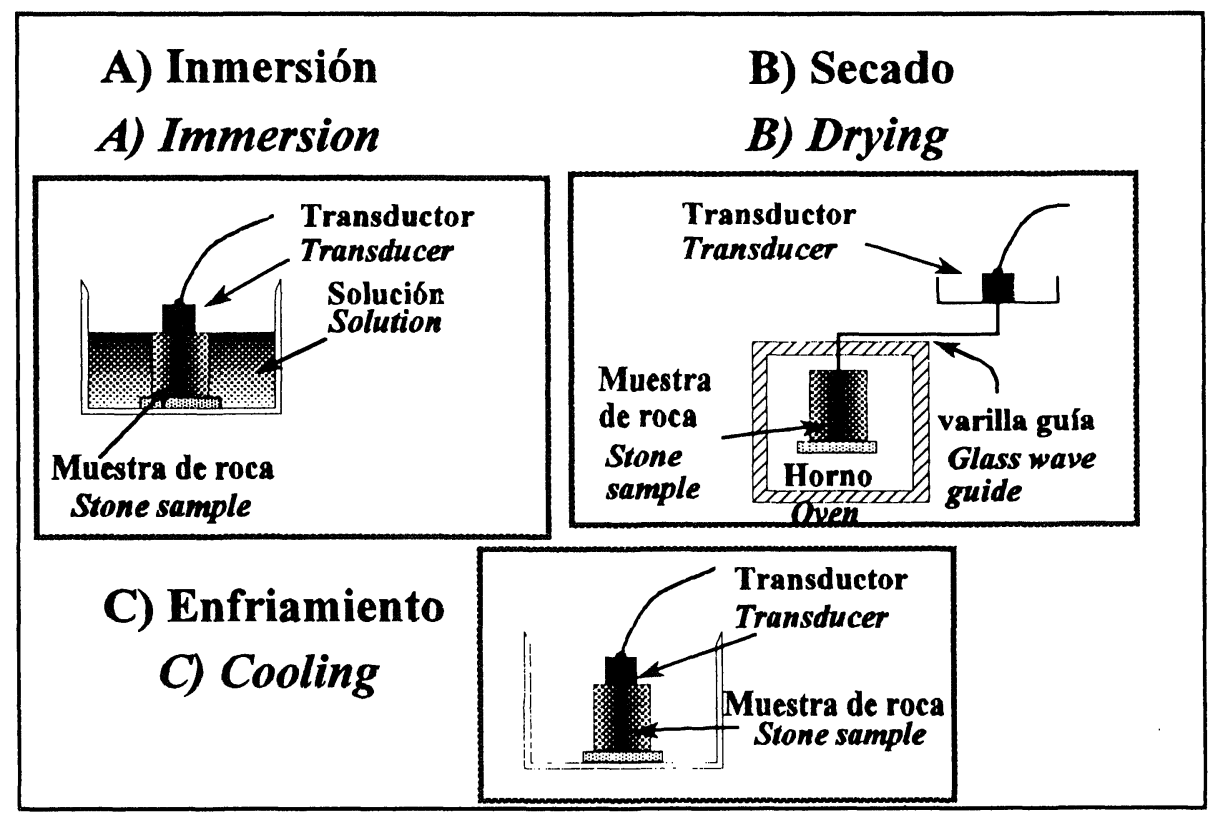

Fig. 4.- Registro de emisión acústica/actividad microsísmica durante las diferentes etapas de los ciclos de cristalización de sales.

Fig. 4-Acoustic emission/microseismic activity monitoring during the different stages of salt crystallisation cycles. 


\section{CARACTERÍSTICAS DEL SULFATO DE SODIO}

Las características de esta sal que van a condicionar sus mecanismos de actuación en los materiales rocosos son: sus diferentes estados de hidratación, su solubilidad y el polimorfismo del sulfato de sodio anhidro.

En condiciones ambientales presenta dos fases estables, la mirabilita $\left(\mathrm{Na}_{2} \mathrm{SO}_{4} \cdot 10 \mathrm{H}_{2} \mathrm{O}\right)$ y la thenardita $\left(\mathrm{Na}_{2} \mathrm{SO}_{4}\right)$. La presencia de una u otra dependerá de la humedad y la temperatura $(4,5,6)$.

En cuanto a su solubilidad, es una de las sales mejor conocidas. La solubilidad aumenta marcadamente hasta $\operatorname{los} 32,4^{\circ} \mathrm{C}$. Por encima de esta temperatura decrece lentamente a medida que aumenta la temperatura. La fase estable, por debajo de $32,4^{\circ} \mathrm{C}$, es el decahidrato mientras que la fase estable, por encima de esa temperatura, es el sulfato anhidro (7). La solubilidad de la thenardita y de la mirabilita es del $34,5 \%$ y $16 \%$ de $\mathrm{Na}_{2} \mathrm{SO}_{4}$ en agua, a $20^{\circ} \mathrm{C}$, respectivamente (8).

Otra característica importante es el polimorfismo del sulfato de sodio anhidro. En la literatura se mencionan 5 fases:I, II, III, IV y V, de las cuales, la III y V son las que se pueden encontrar en condiciones ambientales. La fase $\mathrm{V}$, en condiciones ambientales, es estable mientras que la III es metaestable y tiende a convertirse lentamente en fase V (9). Ambas son ortorrómbicas, pero presentan densidades ligeramente diferentes (7).

Diferentes autores $(10,11,12)$, haciendo precipitar cristales de $\mathrm{Na}_{2} \mathrm{SO}_{4}$ a partir de soluciones acuosas a diferentes temperaturas $\left(40,50,60\right.$ y $\left.70^{\circ} \mathrm{C}\right)$, obtuvieron cristales, predominantemente de fase III a 60 y $70^{\circ} \mathrm{C}$ y de fase $\mathrm{V}$ a 40 y $50^{\circ} \mathrm{C}$.

\section{RESULTADOS}

Todas las rocas ensayadas sufren un deterioro a lo largo de los ciclos que depende de su porosidad y configuración del sistema poroso (13). La piedra que alcanza un mayor deterioro es la dolomía de Laspra, seguida de la caliza de Murcia y de la dolomía de Vinaixa. Las pérdidas de peso al final de nueve ciclos es, aproximadamente, $40 \%, 11 \%$ y $1 \%$, respectivamente. En todas ellas, la pérdida de material se produce siempre durante la etapa de inmersión.

La actividad microsísmica generada durante los ciclos difiere de uno a otro material. En la dolomía de Laspra no se detectó emisión acústica en ninguna etapa, mientras que en las piedras de Vinaixa y Murcia se

\section{SODIUM SULPHATE CHARACTERISTICS}

The sodium sulphate characteristics that determine stone decay mechanisms are: its different hydration states, its solubility and the polymorphism of the anhydrous sodium sulphate.

It has two stable phases at room conditions: mirabilite $\left(\mathrm{Na}_{2} \mathrm{SO}_{4} 1 \mathrm{OH}_{2} \mathrm{O}\right)$ and thenardite $\left(\mathrm{Na}_{2} \mathrm{SO}_{4}\right)$. The appearance of one or the other depends on humidity and temperature $(4,5,6)$.

Sodium sulphate is one of the best known salts in terms of solubility which increases remarkably up to $32.4^{\circ} \mathrm{C}$. Above this temperature, solubility slowly decreases as temperature increases. The stable phase under $32.4^{\circ} \mathrm{C}$ is decahydrate (mirabilite) whereas anhydrous sodium sulphate (theriardite) is the stable phase above this temperature (7). Thenardite and mirabilite solubilities at $20^{\circ} \mathrm{C}$ are $34.5 \%$ and $16 \%$ of $\mathrm{Na}_{2} \mathrm{SO}_{4}$ in water respectively (8).

Another important characteristic is the anhydrous sodium sulphate polymorphism. Five phases are mentioned in the literature: I, II, III, IV and V. Phases $I I I$ and $V$ can be found at room temperature. At these conditions, phase $V$ is stable whereas phase III is metastable and tends to slowly revert to phase $V$ (9). Both of them are orthorhombic but they have slightly different densities (7).

Different authors $(10,11,12)$ grew $\mathrm{Na}_{2} \mathrm{SO}_{4}$ crystals from aqueous solutions at different temperatures (40, 50, 60 and $70^{\circ} \mathrm{C}$ ). They obtained crystals mainly of phase III at 60 and $70^{\circ} \mathrm{C}$ and phase $V$ at 40 and $50^{\circ} \mathrm{C}$.

\section{RESULTS}

All the tested stones show a decay throughout the cycles depending on the porosity and pore size distribution (13). Decay was higher in Laspra dolomite followed by Murcia limestone and Vinaixa dolomite. Weight loss after nine cycles is about 40\%,11\% and $1 \%$ respectively. Material loss is always produced during immersion.

The monitored $A E$ rate differs from one material to another. In Laspra stone no AE was detected in any stage. In Vinaixa and Murcia stones significant acoustic emission levels appeared mainly during 
registraron niveles significativos de emisión acústica durante la etapa de enfriamiento, aunque también se registró una emisión acústica insignificante durante los primeros minutos de la etapa de inmersión. Durante la etapa de secado no se detectó emisión acústica.

En términos generales, la emisión acústica registrada parece ser mayor en la piedra de Murcia que en la de Vinaixa (Fig. 5). cooling stages. Minor and irrelevant $A E$ was monitored during the first minutes of immersion stages. No AE was monitored during drying.

On the whole, the monitored acoustic emission seems to be higher in Murcia limestone than in Vinaixa dolomite (Fig. 5).

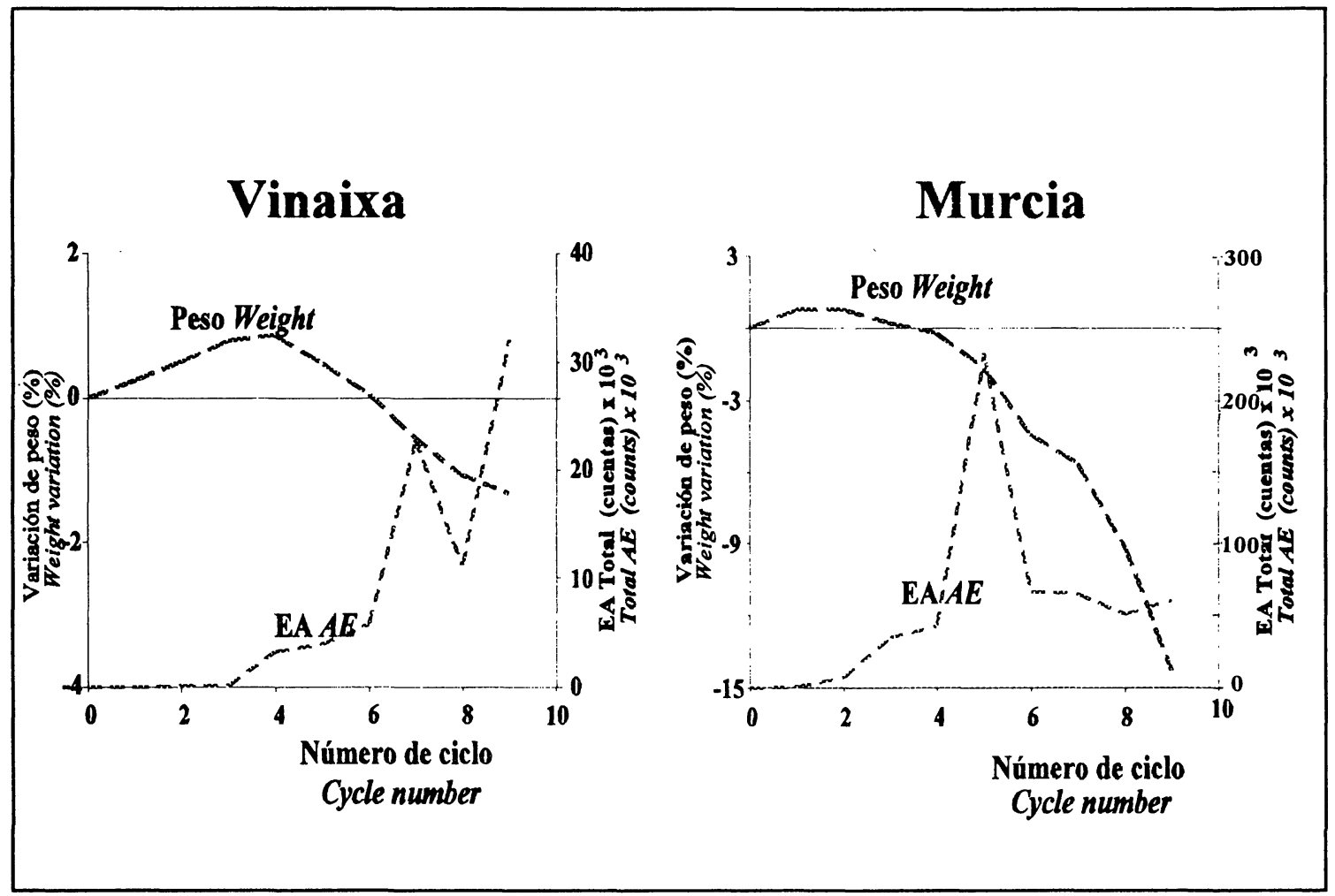

Fig. 5: Variación de peso y registro de emisión acústica durante la etapa de enfriamiento. Izquierda: dolomía de Vinaixa. Derecha: caliza de Murcia.

Fig. 5: Weight variation and acoustic emission monitored during cooling. Left: Vinaixa dolomite. Right: Murcia limestone.

Para conocer el papel desempeñado por la sal en la generación de $\mathrm{EA}$, se ha hecho precipitar durante 14 horas a $60^{\circ} \mathrm{C}$, en un vaso de vidrio PYREX, sulfato sódico a partir de una solución acuosa al $14 \%$ de sulfato de sodio decahidratado. Posteriormente se ha realizado una etapa de enfriamiento a condiciones ambientales y se ha monitorizado la EA durante esta etapa.

Dependiendo de la cantidad de solución, la evaporación y la precipitación de la sal es completa o parcial al final de la etapa de secado.

Cuando la precipitación es completa (no queda resto de solución) hay un registro elevado de EA durante el
In order to understand the role of the salt on the generation of acoustic emission in this test, sodium sulphate has been precipitated in a PYREX glass vessel from a 14\% aqueous solution of sodium sulphate decahydrate during 14 hours of drying at $60^{\circ} \mathrm{C}$. Then, the acoustic emission generated by the precipitated salt was monitored during cooling at room conditions.

Depending on the amount of solution, evaporation and salt precipitation were either complete or partial at the end of the drying stage.

When precipitation was complete (no solution remains in the vessel) the acoustic emission recorded during 
enfriamiento. En este caso, la sal presente al principio y final del enfriamiento es sulfato anhidro, tanto en fase III como en fase V (determinado mediante difractometría de rayos $\mathrm{X}$ ). Además, los valores de emisión acústica son tanto más altos cuanto mayor es la cantidad de sulfato sódico precipitado (Fig. 6).

Cuando la precipitación es parcial, queda un resto de solución al final del secado que cristaliza a lo largo del enfriamiento. El registro de emisión acústica es menor que en el caso anterior. Cuando existe un cantidad considerable de solución sobresaturada al principio de la etapa de enfriamiento, cristaliza sulfato de sodio decahidratado y el registro de emisión acústica es muy bajo (14). cooling was very high. In this case, the salt detected by $X$ Ray Diffractometry was anhydrous sodium sulphate in phase III and $V$, both at the beginning and at the end of the cooling stage. Moreover, the higher is the amount of precipitated salt, the higher is the monitored AE rate (Fig. 6).

When precipitation was partial a rest of solution was found at the end of the drying stage which crystallised during the cooling stage. The AE monitoring was lower than in the previous case. When a substantial amount of supersaturated solution was found at the beginning of the cooling stage, sodium sulphate decahydrate crystallised and only a minor $A E$ was recorded (14).

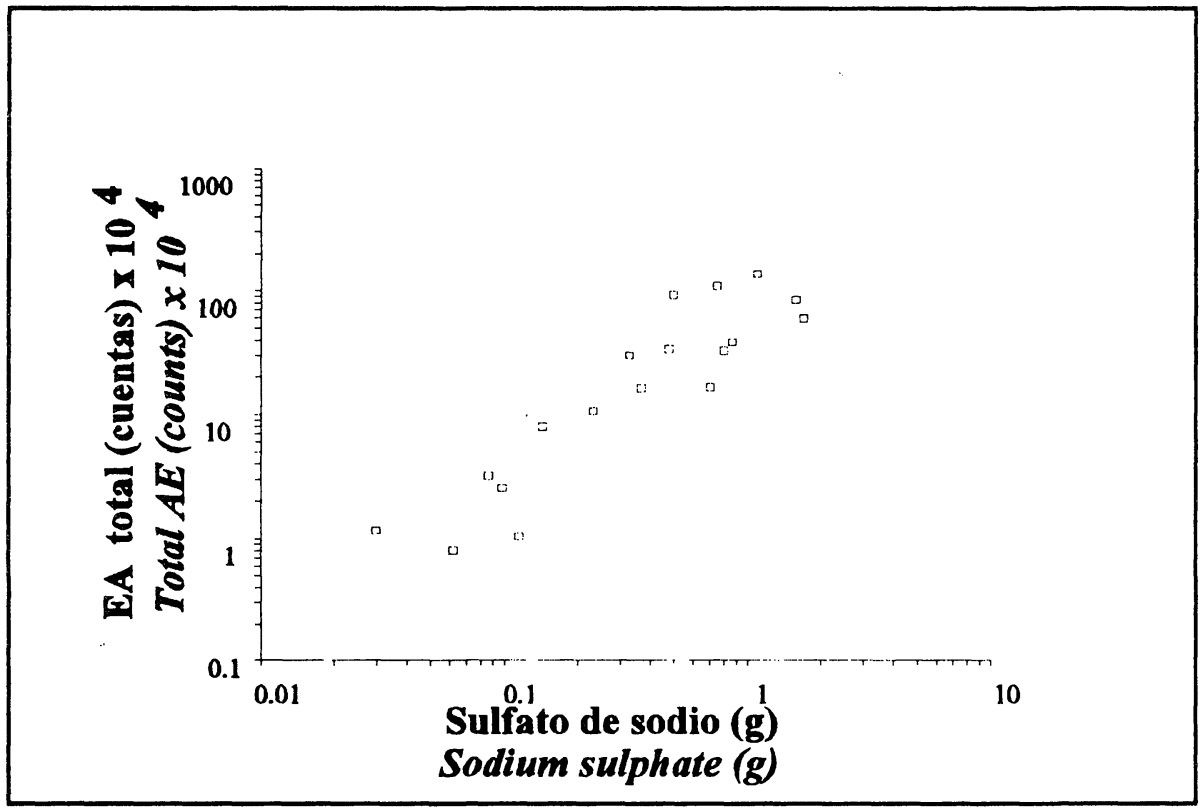

Fig. 6.- Registrode emisión acústica frente a la cantidad de sulfato de sodioprecipitado durante la etapa de secado.

Fig. 6.- Acoustic emission monitored during cooling versus amount of sodium sulphate precipitated during drying.

\section{DISCUSIÓN Y CONCLUSIONES}

A partir de los resultados obtenidos en estas condiciones de ensayo, parece que se pueden establecer dos modelos de comportamiento del sistema $\mathrm{Na}_{2} \mathrm{SO}_{4}-\mathrm{H}_{2} \mathrm{O}$, y por lo tanto de los mecanismos de deterioro generados por esta sal en relación con las características del sistema poroso de las piedras. Estos dos modelos están condicionados por el grado de secado alcanzado durante dicha etapa del ensayo. Así:

A) Si el secado no es completo, queda algo de solución en el interior de la roca al final de la etapa de secado. Durante la etapa de enfriamiento tiene lugar

\section{DISCUSSION AND CONCLUSIONS}

From the results obtained in these test conditions, two models of $\mathrm{Na}_{3} \mathrm{SO}_{4}-\mathrm{H}_{2} \mathrm{O}$ system behaviour, and therefore of decay mechanisms generated by this salt, may be established in relation to stone pore distribution characteristics. These two models are determined by the degree of drying during this stage. Thus:

A) If drying is not complete, some solution remains inside the stone at the end of the drying stage.

During cooling the crystallisation of the sodium 
una cristalización del decahidrato, no detectándose EA. En la siguiente etapa de inmersión, se produce una disolución de la sal hidratada. Si se alcanza la sobresaturación, cristalizará el decahidrato.

B) Si el secado es completo, no queda ningún resto de solución y la sal precipitada es sulfato de sodio en fases III y V. Durante la etapa de enfriamiento se producen cambios en la sal anhidra precipitada (cristalográficos, texturales, microfisuración...). En este caso se registra emisión acústica. En la posterior etapa de inmersión tiene lugar una disolución de la sal anhidra. Si se alcanza la sobresaturación en sulfato decahidrato, la sal cristalizará, con el consecuente aumento de volumen (15).

$\mathrm{El}$ que tenga lugar uno $\mathrm{u}$ otro mecanismo viene determinado por la configuración del sistema poroso de las piedras, que condicionará la toma de solución durante la inmersión, la evaporación de la misma y la precipitación de la sal durante el secado. Así, en la piedra de Laspra, muy porosa y con radios de acceso de poro muy pequeños, al final de la etapa de secado queda un resto de solución, que dará lugar a la cristalización de sulfato hidratado durante el enfriamiento (modelo A). En las otras dos rocas (Vinaixa y Murcia), con mayores radios de acceso a los poros, el secado generalmente es completo, obteniéndose al final de esta etapa sulfato anhidro en fases III y V (modelo B)

Esto se ha corroborado comparando la variación de peso durante el enfriamiento en las dolomías de Laspra y Vinaixa (Tabla II). En Vinaixa (con mayores radios de acceso de poro) se observa un incremento de peso sulphate decahydrate takes place and no $A E$ is monitored. In the following immersion stage the hydrated salt dissolves. If supersaturation is reached, sodium sulphate decahydrate crystallises.

B) If drying is complete, no rest of solution remains within the stone and anhydrous sodium sulphate precipitates as phases III and V. During the cooling stage some changes (crystallographic, textural, microfissuration...) can occur in the precipitated anhydrous salt. In this case, AE is monitored. In the following immersion stage the precipitated anhydrous salt dissolves. If supersaturation in decahydrate sodium sulphate is reached, this salt crystallises, producing a volume increase (15).

Both proposed models are conditioned by the stone pore network, that influences the solution absorption during immersion and solution evaporation and salt precipitation during drying. In this way, in Laspra dolomite, with high porosity and very small pore opening radii, a rest of solution remains at the end of the drying stage. This can lead to the sodium sulphate decahydrate crystallisation during cooling (model A). In the other two rocks (Vinaixa and Murcia), with larger pore opening radii, the drying is usually complete. In this case, anhydrous sodium sulphate in phases III and V can be found at the end of the drying stage (model B).

This has been demonstrated comparing the weight variation during cooling in Laspra and Vinaixa dolomites (Table II). In Vinaixa dolomite, with larger pore opening radii, a weight increase is observed

\section{TABLA II (TABLE II)}

Captación de vapor de agua en las Dolomías de Vinaixa y Laspra bajo diferentes condiciones de ensayo

(Water vapour uptake by Vinaixa and Laspra dolomites under different test conditions)

\begin{tabular}{|c|c|}
\hline & Condiciones (Conditions) \\
\hline \multirow{2}{*}{$\begin{array}{l}\text { Variación de peso }(\%) \\
\text { (Weight variation }(\%) / \\
\text { Vinaixa }\end{array}$} & $\begin{array}{l}\text { Ensayo de cristalización de sales. Ciclo } 6.3 \text { horas de enfriamiento } \\
\left(70 \% \mathrm{HR} ; 20^{\circ} \mathrm{C}\right) \text {. } \\
\text { (Salt crystallisation test. Cycle } 6.3 \text { hours cooling }\left(70 \% \mathrm{RH} ; 20^{\circ} \mathrm{C}\right) \text {. }\end{array}$ \\
\hline & 0,05 \\
\hline \multirow{2}{*}{$\begin{array}{l}\text { Variación de peso }(\%) \\
\text { (Weight variation }(\%)) \\
\text { Laspra }\end{array}$} & $\begin{array}{l}\text { Ensayo de cristalización de sales. Ciclo } 6.3 \text { horas de enfriamiento } \\
\left(70 \% \mathrm{HR} ; 20^{\circ} \mathrm{C}\right) \text {. } \\
\text { (Salt crystallisation test. Cycle } 6.3 \text { hours cooling }\left(70 \% \mathrm{RH} ; 20^{\circ} \mathrm{C}\right) \text {. }\end{array}$ \\
\hline & $-0,24$ \\
\hline \multirow{2}{*}{$\begin{array}{l}\text { Variación de peso }(\%) \\
\text { (Weight variation }(\%) / \\
\text { Laspra }\end{array}$} & $\begin{array}{l}\text { Contenido en humedad higroscópica }\left(23^{\circ} \mathrm{C} ; 60 \% \text { HR). } 3 \text { horas }\right. \\
\text { (Hygroscopic moisture content }\left(23^{\circ} \mathrm{C} ; 60 \% \text { RH). } 3 \text { hours). }\right.\end{array}$ \\
\hline & 0,7 \\
\hline
\end{tabular}


durante el enfriamiento. Sin embargo, en Laspra, que es una piedra con una gran capacidad para captar vapor de agua (Tabla II), hay una disminución de peso, lo que indica que en esta piedra aún quedaba un resto de solución después de la etapa de secado.

Estos modelos propuestos sólo serán válidos para las condiciones de ensayo utilizadas (14). Los fenómenos producidos durante el ensayo de cristalización de sales son bastante complejos y dependen estrechamente de las condiciones experimentales $(6,16,17,18)$.

Parece, pues, que la técnica de emisión acústica puede resultar válida para interpretar los mecanismos de deterioro de las rocas porosas por sales solubles, al menos en las condiciones en las que se han realizado estos ensayos.

\section{AGRADECIMIENTOS}

A la CICYT (Comisión Interministerial de Ciencia y Tecnología) por la financiación del proyecto: SEC95-0501. during cooling. However, in Laspra dolomite, with a high capacity to take water vapour (Table II), a weight decrease occurs suggesting an incomplete precipitation of anhydrous salt during drying.

These proposed models are only valid for these test conditions (14). Phenomena occurring during crystallisation test are quite complex and strongly dependent on experimental conditions $(6,16,17,18)$.

Therefore, the acoustic emission technique has proved to be useful to interpret the stone decay mechanisms by salts, at least in the performed test conditions.

\section{ACKNOWLEDGEMENTS}

The authors wish to acknowledge CICYT (Comisión Interministerial de Ciencia y Tecnologia) (Spain), project: SEC.95-0501

\section{BIBLIOGRAFÍA}

(1) MONTOTO, M.; ESBERT, R.M.; SUÁREZ DEL RÍO, L.M.; RUIZ DE ARGANDOÑA, V.G.; CALLEJA, L. Y GROSSI, C.M.: "Acoustic emission in stone conservation". Acoustic Emission/Microseismic Activity in Geologic Structures and Materials V. Trans. Tech. Publications, 1995, pp. 665-684. .

(2) HARDY, H.R, Jr.: "Applications of Acoustic Emission Techniques to rock and rock structures: A state-of-the-Art Review". ASTM Special Technical Publ., 750, 1982, pp. 4-92

(3) RILEM: "Essais recommandées pour l'altération des pierres et évaluer l'efficacité des méthodes de traitment". Matériaux et Constructions, 13 (75), 1980, pp. 216-220.

(4) ARNOLD, A.: "Behaviour of some soluble salts in stone monuments". $2^{\text {nd }}$ International Symposium on the Deterioration of Building Stones, Athens, 1976, pp. 27-36.

(5) SPERLING, C.H.B. Y COOKE, R.U.: "Laboratory simulation of rock weathering by salt crystallisation and hydration processes". Earth Surface Processes and Landforms, 10, 1985, pp. 541-555.

(6) DOHENE, E.: "In situ dynamics of sodium sulfate hydration and dehydration in stone pores: observation at high magnification using the environmental scanning electron microscope". III International Symposium on the Conservation of Monuments in the Mediterranean Basin. Venice, 1994, pp. 143-150.

(7) CHRÉTIEN, A.; KOHLMULLER, R.; PASCAL, P. Y ROLLET, A.P.: "Nouveau traité de chimie minérale". Tome II (Premier Fascicule) "Litium, Sodium". Publié sous la direction de P. Pascal. Edit. Masson et Cie. París. 1966.

(8) BRAITSCH, O.: "Salt deposits. Their origin and composition". Springer, 1971, pp. 7-61.

(9) MOFFADEL, N.; BOUZAZIZ, R. Y MAYER, M.: Le polymorphisme du sulfate de sodium anhydre et les phases intermédiaries, glasérite et aphtitalite, dans le binaire $\mathrm{Na}_{2} \mathrm{SO}_{4}-\mathrm{K}_{2} \mathrm{SO}_{4}$ ". Thermochimica Acta, 185, 1991, pp. 141-153.

(10) CHOI, B.K.; LABBÉ, H.J. Y LOCKWOOD, D.J.: "Raman spectrum of $\mathrm{Na}_{2} \mathrm{SO}_{4}$ (Phase III)". Solid State Communications, 74,2 1991, pp. 109-113. 
(11) CHOI, B.K. Y LOCKWOOD, D.J.: "Ionic conductivity and the phase transitions in $\mathrm{Na}_{2} \mathrm{SO}_{4}$ ". The American Physical Society, 40, 7, 1989, pp. 4683-4689.

(12) AMIRTHALINGAM, V, KARKHANAVALA, M.D. Y RAO, U.R.K.: "Topotaxic phase change in $\mathrm{Na}_{2} \mathrm{SO}_{4}$ ". Acta Cryst. A33, 1977, pp.522-523.

(13) GROSSI, C.M.: "Cristalización de sales en rocas monumentales porosas y su auscultación mediante emisión acústica". Tesis Doctoral, Área de Petrología. Dep. de Geología. Universidad de Oviedo. 1992.

(14) GROSSI, C,M.; ESBERT, R.M.; SUÁREZ DEL RÍO, L.M.; MONTOTO, M. Y LAURENZI-TABASSO, M.: "Acoustic emission monitoring to study sodium sulphate crystallisation in monumental porous carbonate stones". Studies in Conservation. 1997. (En prensa).

(15) McMAHON, D.J., SANDBERG, P., FOLLIARD, K. Y MEHTA, P.K.: "Deterioration mechanisms of sodium sulfate". $7^{\mathrm{h}}$ Int Congress on Deterioration and Conservation of Stone, Lisbon, 1992, pp. 705-714.

(16) PRICE, C.A.: "The use of sodium sulphate crystallisation test for determining the weathering resistance of untreated stone". International Symposium on Deterioration and Protection of Stone Monuments, Paris, 3.6, 1978,10 p.

(17) CHATTERJI, S. CHRISTENSEN, P. Y OVEGAARD, G.: "Mechanisms of breakdown of natural stones caused by sodium salts". $3^{\text {rd }}$ International Congress on the Deterioration and Preservation of Stones. Venice, 1979, pp. 131-134.

(18) SPERLING, C.H.B. Y COOKE, R.U.: "Salt weathering in arid environments II. Laboratory Studies". Papers in Geography 9. 1980 .

\section{publicación del IETCC/CSIC}

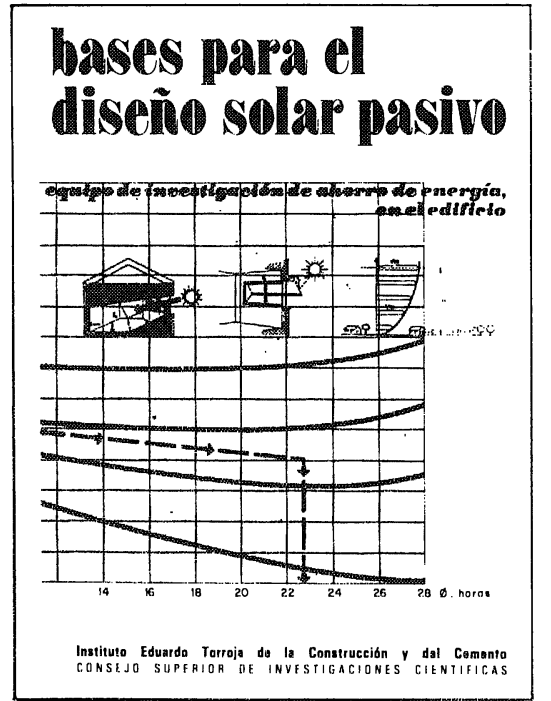

Equipo de Ahorro de Energia en el edificio

Dirección y coordinación: Arturo García Arroyo

M. ${ }^{a}$ José Escorihuela

José Luis Esteban

José Miguel Frutos

Manuel Olaya

Bernardo Torroja caso y lugar.
Las dificultades de suministro y el alto coste de los productos energéticos convencionales han despertado la atención de los usuarios, técnicos e industriales de la edificación hacia los procedimientos y sistemas en que se basa el aprovechamiento de otras fuentes alternativas de ha generado un rápido desarrollo industrial y comercial que, en opinión de los autores de este libro, arrastran los siguientes defectos: un mimético tecnologismo respecto de los sistemas convencionales que violenta las pe culiaridades de la energia solar (baja densidad $y$ variabilida en el tiempol $y$ una escasa selectividad en la aplicación de los sistemas y procedimientos pasivos dando origen a un ecumenismo arquitectónico solar, al margen de las condiciones climáticas y funcionales específicas de cada

En este libro, utilizando criterios y metodologia pedagógicos, se dan los fundamentos e instru mentos teórico-prácticos necesarios para el planteamiento de todo proyecto arquitectónico sola pasivo de acuerdo con los principios éticos y económicos de conservación y ahorro de energia. Es decir: respeto de los presupuestos bioclimáticos, búsqueda de la máxima captación y acumulación de la radiación solar, y esmero en el aislamiento térmico de los cerramientos.

Un volumen encuadernado en cartulina ibiza plastificada, a cinco colores, de $16 \times 23 \mathrm{~cm}$, compuesto de 216 páginas, 217 figuras, 87 gráficos, 19 tablas y 10 cuadros. 